\title{
The Implications of the Accession Agreement of the EU to the ECHR
}

\author{
Valbona Sanxhaktari PhD Cand. \\ Legal Expert, Department of Legislation, \\ Monitoring of Programs and Anticorruption, Office of Prime Minister \\ valbona.sanaxhaktari@gmail.com
}

Doi:10.5901/mjss.2014.v5n16p135

\begin{abstract}
In April 2013 the European Union and the member states of the Council of Europe reached consensus on a draft Agreement on the Accession of the EU to the ECHR. This event represents a milestone development for the protection of fundamental rights in the EU. The Accession has an enormous symbolic value for the European Union. We argue that the Accession Agreement creates strong institutional pressures for the ECtHR to raise its standards of protection up to the level set by the Court of Justice of the EU. This paper examines as well the dialogue between the Court of Justice of the EU and the European Court of Human Rights regarding due process rules in the context of targeted anti-terror sanctions imposed by the UN Security Council. By analysing the references that the two courts make to each other's case law in the recent landmark decisions in Nada and Kadi II, the paper argues that the rivaling yet constructive relationship between CJEU and the ECtHR has played a key role in re-adjusting the balance between international security and fundamental rights in Europe. But what are the effects of accession on the ECHR and its court - the European Court of Human Rights? As the paper suggests, the looming accession of the EU to the ECHR influences the interaction between the two courts, and is already palpable in the case law of both.
\end{abstract}

Keywords: accession of the EU to the ECHR- Court of Justice of the EU - European Court of Human Rights - due process judicial dialogue

\section{Introduction}

The Accession Agreement constitutes the last step of a growing interlocked system of fundamental rights, and intends to enhance the effective enforcement of fundamental rights within this system. The accession will entitle any person, nongovernmental organization or group of individuals to submit the acts, measures and omissions of the European Union, like those of every other High Contracting Party, to the external control of the ECtHR in the light of the rights enshrined in the European Convention of Human Rights- which is even more important due to the transfer of substantial powers from the Member States to the EU. It will also enable the ECJ to apply the Convention directly, without taking recourse to the general principles under Article 6(3) TEU. At the other hand this will allow the European Union to play a full role in proceedings in Strasbourg in cases involving EU law and cement more firmly the role and decisions of the ECtHR in the Union legal order.

Concurrently, the negotiators of the Accession Agreement tried to take into account that the autonomy of EU law should not be prejudiced by the Agreement itself and the subsequent case law of the Strasbourg Court, especially since the Court of Justice of the European Union (ECJ) as well as the courts of the EU Member States are also obliged to ensure the observance and protection of human rights within the Union legal system, under the principle of subsidiarity in Article 35(1) ECHR.

The Charter of Fundamental Rights (the Charter) is often confused with the European Convention on Human Rights (the ECHR), as the Court of Justice of the EU in Luxembourg (the ECJ) is with the European Court of Human Rights in Strasbourg (the ECtHR). Whilst both contain overlapping human rights provisions, an issue we consider in this paper, they operate within separate legal frameworks. The Charter is an instrument of the EU. It is part of EU law and subject to the ultimate interpretation of the ECJ. The ECHR is an instrument of the Council of Europe in Strasbourg, and is interpreted by the ECtHR.

In its September 2012 decision in Nada v. Switzerland, the Grand Chamber of the ECtHR addressed the legality of measures implementing targeted sanctions stemming from the UN Security Council and, relying on the Kadi decision of the CJEU, found a violation of the rights enshrined in the European Convention on Human Rights (ECHR). More recently, in the Kadi Il judgment of July 2013, the CJEU in turn cited the ECtHR and reaffirmed its previous conclusion that Mr Kadi had been deprived of due process rights in being subject to the UN sanctions regime as implemented within the 
European Union. Based on this recent case law, the argument we advance in this paper is that the CJEU and the ECtHR have been influencing each other, and that their interaction, under the looming accession of the EU to the ECHR, has been instrumental to ensure the effectiveness of the protection of due process standards in the European multilevel human rights architecture.

\section{The Direct Consequences of the Accession}

In a renewed political effort to formalize the relationship between the two courts, with the entry into force of the Lisbon Treaty in 2009 and the necessary amendments of the ECHR, the road is now open for the accession of the EU to the ECHR. Pursuant to the new Article 6(2) TEU as well as the new Article 59(2) ECHR, as modified by the 14th Additional Protocol to the ECHR, the negotiating process for the accession of the EU to the ECHR has reached an advanced stage and may soon be concluded with a formal accession document: The Accession Agreement.

The starting point of this analysis is the version of the Draft published on the website of the Council of Europe. This should be the version submitted for the ratification process. In the Draft are explained the legal instruments which shall be used for the Accession. First of all, we should bear in mind that the document, must comply with the protocol for the accession of the EU to the European Convention of Human Rights embodied in the Lisbon Treaty, and the 14th protocol of the ECHR which provides for the accession of the EU to the ECHR.

Both impose that the accession should not undermine the powers and nature of the EU and ECHR. The first area to be affected by the Accession is the jurisdiction of the Court of Justice of the European Union. If one word summarizes the characteristics of the CJEUs jurisdiction it would be the word exclusive. The exclusivity of the jurisdiction is contained in the Treaties, in particular in art. 263 TFEU, where one can easily find that only the Court is entrusted with the review of the acts of the institutions, of the actions promoted by the institutions, and of the actions promoted by individual, natural and legal persons.

Nothing is superior to the CJEU, and there is no appeal against its judgments. We could say that the rule of the Court is the "supreme rule of the land", as happens with many national constitutional Courts. The comparison is not as straightforward though, as the CJEU takes many different roles inside the Union.

The Draft Agreement on the accession of the EU to the ECHR modifies the latter in such a way as to accommodate 'the specific situation of the EU as a non-State entity with an autonomous legal system that is becoming a Party to the Convention alongside its own member States. This includes, most notably for the relationship between the two courts, the so-called 'co respondent mechanism' and, as a part thereof, the prior involvement of the CJEU. The former means that where either Member States are implementing EU law or where primary EU law is at stake with regard to alleged violations of Convention rights, the Union and the Member States can respond to the complaint jointly. The latter provides the CJEU with the power to review the compatibility of Union legislation with the ECHR preceding a decision by the ECtHR. This applies whenever Member State courts fail to request a preliminary reference from the CJEU, meaning that the case arrives at the ECtHR without the EU Courts having had the opportunity to review it. This grants the CJEU a privilege that no other court of a ECHR contracting party enjoys. This mechanism represents the most powerful link between the two courts and the greatest potential in intensifying their relationship. Before the ECtHR can rule, the CJEU will always have the opportunity to set the tone. But if the former does not want to fall behind, it will have to align itself, and go beyond, the standards set by the CJEU.

After the accession of the EU to the ECHR, however, a major institutional change will take place in the relationship between the EU and the ECHR and their respective courts. Since the EU will be a Contracting Party to the ECHR, there would be no reason for the ECtHR to preserve a deferential approach in reviewing action by the EU institutions, including the CJEU. Rather, it seems likely that the ECtHR will adopt vis-à-vis the EU the same full standard of review it employs vis-à-vis the other Contracting Parties to the ECHR. As a result, any lowering of the standard of protection in the EU legal order would come under the scrutiny of the ECtHR.

\section{A Solution to Shared Responsibility? The Co-respondent Procedure and the Role of the ECtHR in the Co- respondent Procedure}

The co-respondent procedure was mentioned for the first time in the "Draft revised elements prepared by the Secretariat on the Introduction of a co-respondent mechanism". Now this procedure is enshrined in art. 3 of the Draft for the Accession. The members of the Working Group CDDH-EU reached an agreement on the article during the meeting, held in June 2011. The procedure explained is useful for understanding the crucial role that the two Courts will play after the Accession. The hypothesis of shared responsibility could arise from the application of a judgment of the CJEU where the 
ECtHR has found a violation of the Convention, or requires13 the CJEU to pronounce itself before the final decision of the ECtHR. This procedure should be triggered only in the case in which the Union Member State is found responsible of an infringement of the Convention together with the EU. This means that both the MS and the EU could be held liable for the violation of the Convention in front of the ECtHR. The aim of article 3 of the Draft is to put to an end a twofold problem:

i) The procedure to be adopted when the breach of the MS is arising from the Union law and vice versa, explained in art 3.2, 3.3, 3.4;

ii) The attempt to resolve the relationships between the CJEU and Convention, (see in particular art. 3.615), regulating the cases in which the CJEU is due to give an advanced preliminary ruling while the case is pending in front of the CJEU.

The mechanism provided in article 3.2, 3.3, 3.4 aims to resolve three different cases of shared responsibility, which are worth examining in depth in the next paragraphs. Becoming a co-respondent party in a proceeding in front of the ECtHR, even if the conditions laid down in paragraph 2 and 3 are satisfied, is not an automatic process. The decision should be taken, according to paragraph 5 of art. 3 of the Draft, by the becoming a co-respondent party in a proceeding in front of the ECtHR, even if the conditions laid down in paragraph 2 and 3 are satisfied, is not an automatic process. The decision should be taken, according to paragraph 5 of art. 3 of the Draft, by the attributing to art 3.5 the first or the second meaning might have many different consequences.

Adopting the first interpretation means that the right of initiative pertains to the MSs and the only way to became a co-respondent is making an official request to the ECtHR. This option seems to undermine the scope of the article, because a MS/HCP will become involved in the proceeding only at its own desire, and the effectiveness of the co respondent procedure will be in danger. The second interpretation seems more consistent with the aim of the article and the scope of the agreement, because it confers the power of initiative both on the HCP and on the ECtHR.

This is clearly the best solution, because it means that even if the HCP is not keen to recognize its role in the breach, the ECtHR could declare it co-respondent. If the Court ensures that the correct interpretation is this one, it could be another sign that no preferential treatment is accorded to the EU25. The explanatory report at the end of the Draft, however, is quite clear in putting emphasis on the first interpretation.

As it is written: "No High Contracting Party may be compelled against its will to become a co-respondent. This reflects the fact that the initial application was not addressed against the potential co-respondent, and that no High Contracting Party can be forced to become a party to a case where it was not named on the original application". This official position is capable of undermining the effectiveness of the procedure. It seems hard, if not impossible, to compel the EU/ MS to became part in the judgment. If, on the contrary, we look at the political side of the question, it is obviously less dangerous to provide an emergency exit like this one. Presuming that the aim of the Draft is to solve the shared responsibility issue, to leave the ultimate decision of the co-responsibility to the MS/HCP means that the usefulness of this procedure is undermined. The co - respondent procedure described in these articles seems to leave little space for the principle of equivalent protection of the Bosphorus ruling. This procedure seems clearly addressed in repealing the previous system based on the presumption of compliance with the Convention when the MS/HCP is acting under the protection of EU law.

\section{Is Judicial Review the Real Solution for the Protection of Fundamental Rights?}

The Draft, once entered into force, will be one of the most important documents to be examined in the next years. Its importance is crucial for the realization of an integrated and consistent legal order throughout Europe, and it represents a turning point for the future. Its drafting style suggests however that most of the work will bear on the shoulders of the Courts. This gives grounds for engage in some considerations on the nature of human rights protection in Europe. The core of the Draft is represented by the co-respondent procedure established in order to enhance the relationships between the two Courts, and it strengthens the enforcement of fundamental rights judicial review. Art 4, 5, 6 of the Draft deals with different arrangements concerning the judicial review of the ECtHR. Art.7 deals with the participation of the EU to the Committee of Ministers, which is entrusted with power of enforcing the judgments of the ECtHR. Five articles of ten, in the Draft, aim to enhance the judicial review of the CJEU-ECtHR.

This gives to the Courts a leading role in the process of integration of Europe. But in respect to the future of the protection of fundamental rights, this Court-leaded process unbalances the role played by judicial review in the application of human rights. Von Bogdandy clarified that without judicial review is impossible to respect human rights. But, on the other side, we must not forget that judges are not politicians. The "scarce" democratic legitimacy of the jurisdictional authorities in general could foster, in the case of the CJEU, the democratic deficit of the EU institutions, which is far from being completely repealed. The Draft has the concrete risk of unbalancing the protection of fundamental 
rights on the side of judicial remedies, as it is too much concerned with the judicial structure, and less on the policy interaction between the Council of Europe and the EU. The EU has still very little competences on fundamental rights, and the Council of Europe mainly produces soft law.

It is not obviously maintained that judicial protection should be decreased, but it could be desirable a much more policy oriented approach. A higher level of involvement of people in the decision-making process of protection of human rights could reveal itself a powerful instrument to verify when there is an European or national consensus on the interpretation of rights. What should be avoided, in the enforcing fundamental rights through judicial review, is that judges of the highest European Courts use their power to take the chair of the national legislator, attempting to create the consensus necessary for the affirmation of controversial positions (for instance in the complex field of non-discrimination, on grating human rights to companies, or in establishing new categories of rights) with the means of judgments. This large amount of powers should be used wisely, in order to avoid the increasing of the distance between the people of Europe and the institutions. Perhaps the most valuable solution could be the adoption of a margin of appreciation doctrine for fundamental rights inside the EU. The prudent approach which characterize this doctrine could be regarded as a valid surrogate of the democratic legitimacy of the national Parliaments in the most sensitive issues.

\section{The Indirect Consequences of the Accession}

The Accession has an enormous symbolic value for the European Union. The CJEU, while accepting the jurisdiction of the ECHR, could play an important role in the multi-level system of protection of fundamental rights in Europe. And this reveals that the Draft will have the effect of reverting the controversial relationship between the two Courts to enhance fundamental rights protection in Europe. But more than fundamental rights, a major effect on the jurisdictional architecture of Europe is that the Accession could see the day of a new Constitutional Court, the Court of Justice of the EU. The considerations made above on the Draft and the Court relationship foster what could be defined as the Constitutional Character (or nature) of the CJEU. Considering the Luxembourg Court as a real Constitutional Court only because of the Accession seems untimely. There are, however, a number of factors which reveal that the CJEU is commencing to behave with the full powers of a Constitutional Court:

i) The binding force of the Charter, after the entrance into force of the Lisbon Treaty, provides the possibility of enforcing human rights within the limits established by article 6 TEU and article 51 and 53 of the Charter.

ii) The increased legitimacy given by the judicial review of the ECHR after the Accession will reduce the opposition of the national constitutional courts.

iii) Bosphorus creates the conditions of harmony between the Courts to set up the binding force of the Charter without fear (for the CJEU) of being entangled in a Matthews like decision.

iv) The recent developments in the case law of the CJEU. The first condition has been deeply explored by several scholars. The Charter is a powerful instrument and contains plenty of social rights which needs to be enforced and now are in the process of being enforced by the CJEU. It has been provided, however, with two strong horizontal provisions with the aim of limiting the effects of the Charter to the vertical relation between citizens and the institutions. We must not forget that even if the CJEU is acting, since the creation of the Union, under the principle of conferred powers, this did not impede the CJEU in the task of creating the EU Constitutional order, widening the powers of the first Treaties well before the amendments took place. What are then the obstacles impeding the CJEU to behave in the same way with the Charter?

The fourth argument, regarding the recent developments in the case law of the CJEU, seems to be the most interesting. It deals with the fact that the CJEU is starting to enforce the Charter in many different cases, regarding it as a landmark which sounds really close to a fundamental rights Constitution.

In this case law there are two lines of judgments: the first regards the judgments in which the CJEU started to repeal parts of the European legislation inconsistent with fundamental rights contained in the Charter. The second deals with a renewed approach to human rights. After less than one year from the binding force of the Charter, the Court ruled on the compliance of a regulation on privacy (Regulation no. 2008/256 together with Directive no. 95/46) with fundamental rights, repealing the two articles inconsistent with the Charter. But without Bosphorus behind and the Accession in front the CJEU had for sure showed less confidence in holding the reins of fundamental rights. The Schecke case was confirmed by the Court in Association Belge de Consommateurs about insurance premiums. Some insurance companies evaluated that under certain conditions women pay less than men, relying on a derogation provided by Directive 2004/113 EC. The Court declared the article containing the derogation regime to be in breach of the principle of non-discrimination. This behavior could be considered as comparable with many national constitutional courts.

In another recent case, Samba Diouf, the Court verified the compliance of article 39 of the asylum seekers 
directive (Dir. 2005/85 EC) with art. 47 of the Charter. This could be interpreted as another interesting example of the CJEU behaving as a Constitutional Court. The second line of the case law is characterized by a renewed approach to fundamental rights. Since the realization of the four factors described above, the CJEU approached fundamental rights showing less deference to the ECtHR. The Convention, according to the words of the Court, represents a minimum standard of protection of fundamental rights but nothing prevents the Union to grant more extensive protection. In these cases, the Court seems to grant this more extensive protection. It is an important sign, because the CJEU uses the Convention as a minimum standard, but also enforces the protection of the higher standard of the Charter. This behavior is, again, similar to the one of the national constitutional courts, which, starting by the minimum standard of the Convention, enforce the rights contained in the national Constitutions. A good example of this line is DEB case. This case is about the implementation of the directive on legal aid, not wisely transposed in the German legislation. The applicant was an energy company which could not afford a lawyer because of a loss caused by the incorrect transposition of another directive on the access to the gas market. As a consequence DEB applied for legal aid but received a deny, because German legislation allows legal persons to receive the aid only if, lacking of sufficient resources, the failure to pursue or defend the action would run counter to the public interest.

According to the CJEU, the incorrect implementation of Directive 2003/08/EC is against article 47 of the Charter. The CJEU quotes directly the ECtHR to reinforce its decision. In particular the case law of the ECtHR recognizes that the right of legal aid for legal persons is not in principle impossible, but must be analyzed in light of the case. The Luxembourg Court, following the ECtHR, held that is not possible to preclude to legal persons the access to legal aid, but it is for the national Courts to evaluate if this obstacle undermines the very core of the right of access to justice. This interpretation seems to go even farther than the one of the ECtHR, which at the end granted legal aid only to legal person's non-profit making. McB could be argued as another case on the same line of DEB. The case is about the rights of custody of a child, son of an unmarried couple. After gave birth to the baby, the mother went to another MS, exercising her freedom of movement and citizenship rights. Regulation 2201/2003 precludes to the natural father of the baby to obtain the custody of the son without a decision of the national court. The father appealed to the court in order to obtain the son back, but the term for appealing was expired. The national court refers to the CJEU asking if the interpretation of Regulation 2201/2003 made by national legislation was in contrast with article 7 of the Charter, the right of respect of private and family life. In an analogous case, the ECtHR decided that the situation of the natural father was purely discriminatory. The CJEU did not follow the position of the Strasbourg Court. Taking in account article 52.1 of the Charter, the Court held that recognizing the right of the father would be incompatible with the rights and freedom of the others, in this case, the mother. The Court, committing itself to the limits imposed by the Charter, made a balance, and decided to protect the rights of the mother. In this case the CJEU detached itself from the approach of the ECtHR, showing a certain degree of independence from Strasbourg. This case is of interest also because it could be considered another possible clash between the CJEU and the ECtHR, having the two Courts different positions on the same case. The different solution to which the Court came reflects a less deferential approach of the CJEU in respect of the ECtHR, given by the evolution of the protection of fundamental rights generated by the four factors listed at the beginning of this paragraph. Perhaps it reveals the intention of the CJEU to establish its own standard of protection of fundamental rights. A standard which starts by the Convention, but leads also to a different outcome. In any case, this kind of situations will find, after the Accession, a proper judicial review by the ECtHR.

\section{Some Concluding Remarks: The Judicial Dialogue and the Margin of Appreciation}

In the next years after the Accession will be crucial to foster the judicial dialogue which the two Courts undertook with each other's, continuing more than 25 years, since Jhonston, of tradition. Describing the interaction between the two Courts, we spoke about a particular kind of dialogue: jurisprudential teamwork. That is because the two Courts undertook an activity which leads to the affirmation of human rights as the cornerstone of the unwritten Constitution of Europe. In $D E B$ vs Federal Republic of Germany the CJEU on the other side, the margin of appreciation will reveal itself as a powerful instrument to mediate among the different inclinations and attitudes to human rights throughout the Union and the Convention. Otherwise the risk will be that the so called "reverse discrimination" became famous in the internal market of the EU case law could found another field of application. Therefore, the ECtHR will be allowed to apply the Charter to the EU and the MSs, and the Convention to the other HCPs, "discriminating" a contrario the MSs which are bounded by the higher standard of the Charter. The Charter, however, contains the proper legal instruments to solve this dilemma in a way which should be considered at least comparable to the margin of appreciation doctrine of the ECtHR: art. 52.4. The respect of constitutional traditions of MSs, combined with the two horizontal provisions of the Charter, art.51 and 53, will provide the CJEU with the force of mitigating the impact of the higher standard of the Charter in the most sensitive areas of the national legislations. 


\section{References}

Bengoetxea J., The Legal Reasoning of the European Court of Justice, Oxford, Clarendon Press, 1993, 275 p.

Blumann C. and Dubouis L. Droit institutionnel de I'Union européenne, 4th edition. Paris, Lexis Nexis Litec, 2010, 772 p.

Canaj E.-Bana S. E drejta e Bashkimit Europian, Tirana, 2011, fq.49-51.

Canaj E., Analize e disa problematikave mbi te drejtat e emigranteve sipas Kartes se te drejtave themelore te Bashkimit Europian, Revista Jeta Juridike, n. 2, Tirane 2010. (Analysis of some problematic issues on migrants rights according to the Charter of fundamental rights of European Union).

Combacau J. and Sur. S. Droit international public. 9th edition, Paris, Monchrestien Lextenso, 2010, Domat droit public, 745 p.

Craig P. and de Búrca G., European Union Law - Texts, Cases and Materials. 5th edition. Oxford, Oxford University Press, 2011,1111 p.

De Witte B., "Le rôle passé et future de la Cour de justice des Communautés européennes dans la protection des droits de l'homme". in ALSTON P. (ed.) et al. L'Union européenne et les Droits de l'Homme. Bruxelles : Bruylant, 2001, pp. 895-935.

Dimitrijevic V., "Customary Law as an Instrument for the Protection of Human Rights" in Programma Diritti Umani - ISPI Working Papers. Milan : Istituto per gli Studi di Politica Internazionale, 2006, 30 p.

Doğan Y., "The Fundamental Rights Jurisprudence of the European Court of Justice: Protection for Human Rights within the European Union Legal Order" in Ankara Law Review, Ankara University Faculty of Law, 2009, Vol. 6 No. 1 (Summer 2009), pp. 53-81

Dworkin R., Taking Rights Seriously, London, Duckworth, 1978, 368 p.

Groussot X., General Principles of Community Law. Groningen/Amsterdam, Europa Law Publishing, 2006, 432 p. (The Hogendorp Papers 6).

Rideau J. Droit institutionnel de l'Union européenne. 6th edition. Paris: Lextenso éditions, LGDJ, 2010, p 1423

Sudre F. Droit européen et international des droits de l'homme. 10th edition. Paris, Presses Universitaires de France, 2011,868 p. (Collection Droit Fondamental).

Weiler J. H. H. and FRIES S. "Une politique des droits de l'homme pour la Communauté et l'Union européenne ; la question des compétences", in ALSTON P. (ed.) et al. L'Union européenne et les Droits de l'Homme. Bruxelles : Bruylant, 2001, pp. 147-165.

Memorandum on the accession of the European Communities to the Convention for the Protection of Human Rights and Fundamental Freedoms. COM (79) 210 final, 2 May 1979. Bulletin of the European Communities, Supplement 2/79.

Commission Communication on Community accession to the European Convention for the Protection of Human Rights and Fundamental Freedoms and some of its Protocols. SEC (90) 2087 final, 19 November 1990.

Martin Kuijer. "The accession of the European Union to the ECHR". (2011) 3(4) Amsterdam Law Forum <http://ojs.ubvu.vu.nl/alf/article/view/240/428> accessed 7 December 2011;

Besselink, Leonard "The EU and the European Convention of Human Rights after Lisbon: From 'Bosphorus' Sovereign Immunity to Full Scrutiny?" http://papers.ssrn.com/sol3/papers.cfm?abstract_id=1132788; accessed 7 December 2011;

Costello, Cathryn "The Bosphorus Ruling of the European Court of Human Rights: Fundamental Rights and Blurred Boundaries in Europe". Human Rights Law Review. 2006, 6(1), pp. 87-130;

Douglas-Scott, Sionaidh "Case Comment on Bosphorus Hava Yollari Turizm Ve Ticaret Anonim Sirketi v. Ireland", (2006) CMLR, pp. 243-254.

Lock, "End of an Epic? The Draft Agreement on the EU's Accession to the ECHR", 31 Yearbook of European Law (2012), 162-197.

Jacqué, "The Accession of the European Union to the European Convention on Human Rights and Fundamental Freedoms", 48 Common Market Law Review (2011) 995, p. 995.

Stubberfield, "Lifting the Organisational Veil: Positive Obligations of the European Union Following Accession to the European Convention on Human Rights", 19 Australian International Law Journal (2012), 117, p. 117. 